\title{
Researching gender: the challenge of global diversity today
}

\author{
Chia Longman \\ Department of Comparative Sciences of Culture, Ghent University
}

\begin{abstract}
The text of this paper is based on a lecture given at the symposium of the Ghent African Platform "Researching Gender in/on Africa" at Ghent University in December 2009. It addresses some general challenges faced by 'gender studies' as an autonomous field versus 'gender research' as an integrated topic within mainstream disciplines in academia. Gender studies have sometimes superseded 'women's studies' and expanded to cover the terrain of study of various forms of diversity including men's and transgender studies. We will show that the 'mainstreaming' of gender in public policy at local, national and transnational levels is a development which may potentially lead to the loss of a - feminist - political edge. Secondly, while gender studies with their emphasis on socially constructed gender as opposed to biological essentialist understandings of 'sex' appear to face the challenge of a popular 'new biological determinism', it is shown that the binary model of sex/gender in fact has been criticised for some time now from within feminist theory and gender research. This is (selectively) illustrated with research from four disciplines, including the work of African gender studies scholars, i.e. feminist philosophy, social sciences (in particular socio-cultural anthropology), history and biology itself. This then shows how the accusation that gender studies would be 'socially deterministic' without attending to bodily matters or materiality is unfounded. Finally, it is argued that there is still a need for gender studies to become more culturally diverse, more global and transnational in its outlook, by becoming more deeply attuned to the way gender intersects with other forms of difference and taking into account postcolonial critiques of western feminist paternalism, without falling into the trap of cultural relativism.
\end{abstract}

Key words: gender studies, feminism, sex/gender debate, gender mainstreaming, postcolonial critique, cultural relativism, Afrocentrism

\section{Introduction}

In this paper, I present a situated reflection on developments within gender studies, from my position and location as a researcher within a precarious field of study - gender studies - within an academic setting in northwestern Europe i.e. Flanders, Belgium. The term 'situated knowledges' was introduced by Donna Haraway (1988) and is widely used in gender studies, feminist theory and research in order to critique positivist 'masculinist' models of scientific objectivity. Haraway and many other feminist researchers argue for a kind of 'strong objectivity', in which knowledge is always generated from somewhere, and therefore always a 'partial perspective', depending on the subject's location 
and identity (gender, class, ethnicity, etc.) within matrices of difference and inequality.

In this paper I raise some general questions on the status of 'gender studies' as an autonomous field versus 'gender research' as an integrated topic within mainstream disciplines in academia today. Do we still need gender studies? And if so, what particular challenges do gender studies face, including developments such as the growing popularity of biological determinism, and the mainstreaming or 'domestication' of gender, potentially leading to the loss of its - feminist - political edge? And what are the implications of the 'globalization' of gender, with gender studies developing in manifold and locally specific and relevant ways? I argue that gender studies as a field in its own right should be nourished, as it can continue to provide an important and invigorating contribution to much-needed theory formation and research into gender inequality, providing its attention to the way gender intersects with other forms of difference, including cultural and religious subjectivity within a context of global flows and inequalities.

\section{From Women to Gender}

Gender studies today is embedded in (some, but not all) academia as a scholarly discipline or area of research and education in highly variable ways throughout the world. Gender studies emerged from 'women's studies' in an attempt to broaden the scope of the latter in its selective focus on women to be inclusive of other forms of gendered diversity, including masculinity and various forms of gender diversity with an emphasis on the constructed meanings of gender identities across history, culture and society. In northwestern Europe, this shift took place throughout the ig8os and r9gos at different stages, often for various reasons in different localities. For example, the Dutch Journal for Gender Studies (Tijdschrift voor genderstudies) which has existed for thirty years now, was formerly called the Journal for Women's Studies (Tijdschrift voor vrouwenstudies), yet opted to change its name to 'Gender Studies' in 1998. At my home university in Flanders, Belgium, the current Centre for Gender Studies at Ghent University made the shift in title in 1992. A neighbouring university, the Free University of Brussels, changed its centre's name from 'Women's Studies' to 'Gender and Diversity' only five years ago, a name signalling another shift symptomatic of more recent trends that will be discussed below.

However, such adaptations have by no means been straightforward, uncontested nor universal. Firstly, they originated in English-speaking countries and only impacted those countries where English (as a hegemonic language nonetheless) or Anglo-American theories of sexual difference and inequality were imported and continue to dominate many gender studies curricula (Griffin \& Braidotti, 2002: 3). This includes Dutch-speaking Flanders, where 'gender' has been introduced from the English, but is not used in daily language. Secondly, in most of these countries, 'gender studies' have not superseded 'women's studies', but as the names of research centres, educational programmes or course programmes, they often run parallel or sometimes even in symbiosis (e.g. 'Centre for Women's and Gender Studies'). This is the case both in North America, the UK, Scandinavia and the Netherlands, regions in the West where women's/gender studies have been and remain relatively institutionalized. 
The herstory of gender studies tells us that women's studies in academia developed from within the context of second wave feminism in the West. Not only were women's studies practiced by women, a severely underrepresented group in the production of knowledge at that time, but they also functioned as the 'intellectual arm' of the women's movement. However, the notion of 'gender' served women's studies well, in both analytical and political respects. Borrowed from North American psychologists working in the fifties and sixties who were exploring the role of 'nurture' in child development and socialization towards what was then broadly perceived as 'natural' and 'normal' feminine or masculine behaviour, the social constructionist perspective on gender, rather than 'sex' identities and roles was welcomed among feminist scholars in the seventies (Oakley, 1996). Gender was a tool par excellence in combating the determinist argument that 'biology is destiny'. If femininity and masculinity are constructs, psychologically, historically and culturally variable and changeable, the reasoning went, then, so are the power relations between women and men.

Of course, in itself, the idea that masculinity and femininity were contingent was not completely new. Avant la lettre, French existentialist philosopher Simone de Beauvoir (2010, orig. 1949) argued in her monumental feminist classic Le deuxième sexe that women are not born, but become, are in fact made to be women due to political, economic and socio-cultural processes. According to de Beauvoir, women are always defined as the 'quintessential' object or 'other', in a negative relation to the masculine subject or self. US anthropologist Margaret Mead, a direct heir to Boasian cultural anthropology characterised by ethnographic liberalism and the ideology of cultural relativism, had also made a 'constructivist' point through her cross-cultural research on gender roles. As early as the late twenties and thirties of the previous century, Mead made several ethnographic comparisons of remote - then called 'primitive' peoples - where gender role socialization and sexual life seemed very different to ideals and dominant expectations placed on young women and men back home in an industrialized and modern US (Mead 200r \& 2002). Of course, Mead was by no means uncontroversial, and was (mostly posthumously) severely criticised for methodological flaws and also accused of ignoring biology and cultural determinism (Shankman, 2009), an accusation which currently has resurfaced against gender studies, and a point to which I shall return later on.

The idea of gender as a social and cultural construction means the concept could also be employed as an analytical instrument in a way that 'women' could not. Seminal was US historian Joan Scott's (1996) proposed multidimensional model of gender which was subsequently introduced and applied across various disciplines, yet also served as an interdisciplinary research tool. Scott (ibid.) defined gender in the mid-r980s as 'a constitutive element of social relationships based on the perceived differences between the sexes', and secondly, inspired by Foucault, 'as a primary field within which or by means of which power is articulated'. Thus, gender allowed for a broadening of scope beyond women's studies in its focus on the study of 'women', to women in their societal and historical contexts and their associated meanings, and always in relation to equally socially constructed 'men'. 
Of course, for those familiar with gender studies and feminist research, many of these historical developments and 'key thinkers' are well-known, and there is a great deal to synthesize and say about gender and its herstory. From my perspective, I think it cannot be denied that the notion of gender allowed for a much broader perspective than originally projected in women's studies, and I personally employ 'gender studies' as a kind of umbrella term for women's studies, yet also for a number of burgeoning fields such as men's studies, Lesbian, Gay, Bisexual and Transgender studies (LGBT) and queer studies, although not everyone would necessarily agree. Then again, many of those who continue to employ the term 'women's studies' will most probably not avoid the social constructionism implied in the gender perspective as such. Yet, they may argue that a focus on women and their concerns must not disappear in favour of the more 'neutral' gender terminology. One of the main critiques of 'gender' has been the potential neutralizing and therefore de-politicizing implication of the use of the word (Hawkesworth, 1997; Outshoorn, 1998), whereas others may just take advantage of the more 'neutral' gender terminology as a mere strategic manoeuvre to smuggle in women's, or rather feministinspired, research and concerns.

Hence, gender studies is generally held to be more respectable within academia, or more accurately, tolerated. In some cases, gender perspectives have been integrated or 'mainstreamed' into the regular scientific disciplines. I would argue that sometimes this leads to a kind of 'domestication' of gender, whereby constructionist (and deconstructionist) theories of gender difference seem far removed from everyday inequalities and especially the persistent inequality of women worldwide. For example, in an interview some years ago in a Dutch newspaper (De Volkskrant $23 / 09 / 2003$ ), Romaike Zuidema from the University of Amsterdam, remarked that although women's studies originated in the I970s from a feminist perspective, today it has become "a serious scientific area with the central question of how society and culture determine gender identity. Nonetheless, the image of dungaree-wearing lesbians and that of a discipline that supports outdated feminist ideologies does persevere. When you engage in women's studies now, you do not even have to be a feminist. You can even be an anti-feminist. And there are anti-feminists as well." Yet, at the University of Amsterdam, despite its increasing popularity, including among men, she also claims that the field is still not taken seriously. The planned Master programme in Gender and Sexuality, as the programme was to be called at the time, had to be postponed due to budget cuts.

Thus, depending on location, context and whose perspectives we are talking about, both in and outside of academia, 'gender studies' is for some too political, and for others it may not be political enough. The latter interpretation emerges from the concern among many feminist scholars as to the way 'gender' has become respectably integrated or 'mainstreamed' into policy discourse and practice at both local, national and international levels. In her assessment based on a tour of institutions for gender research and centres for women's studies in some west and southern African countries, Signe Arnfred (2004: 89) of the Nordic Africa Institute in Uppsala, 
Sweden, shows how the concept of gender offers a case in point in terms of the way development discourse has become embedded in neo-liberal lines of thought:

“...despite the good intentions by the gender-and-development (GAD) proponents to politicize the (former) WID [women in development] debate, the opposite seems to have happened. [...] ...to a large extent, gender language has implied a de-politisation of women's issues in development, turning gender into a matter of planning and monitoring and not of struggle". Equally ambiguous, Arnfred (ibid.: 89-90) suggests, is the notion of "mainstreaming", which is reduced to a bureaucratic concept and "...makes no attempt to address unequal power relations. Rather it pretends that power struggles and conflicts do not exist, and that it is all just a question of administration." These developments are not at all limited to the field of gender and development, I might add, but seem to characterize many gender-mainstreaming policies everywhere.

In other contexts and discourses, gender is perceived as too political. In 2004, a plea against 'gender feminism' cropped up in a document from the Vatican edited by the then relatively unknown Cardinal Ratzinger, the current Pope Benedict XVI. From the "Letter to the bishops of the Catholic Church on the collaboration of men and women in the church and in the world", I select the following excerpt, which leaves no doubt as to the well-known conservative views held by church authorities on issues of gender roles and women's emancipation:

"In order to avoid the domination of one sex or the other, their differences tend to be denied, viewed as mere effects of historical and cultural conditioning. In this perspective, physical difference, termed sex, is minimized, while the purely cultural element, termed gender, is emphasized to the maximum and held to be primary. The obscuring of the difference or duality of the sexes has enormous consequences on a variety of levels. This theory of the human person, intended to promote prospects for equality of women through liberation from biological determinism, has in reality inspired ideologies which, for example, call into question the family, in its natural two-parent structure of mother and father, and make homosexuality and heterosexuality virtually equivalent, in a new model of polymorphous sexuality."

This excerpt, emphasizing biological determinism vis-à-vis social constructionism, brings me to the second topic of this paper which relates to another central debate and continuing challenge in gender studies, i.e. the sex-gender distinction. From women to gender we go to sex and gender, and back again...

\section{Revisiting Sex Versus Gender}

On the eve of the millennium, in a lecture I attended in Brussels entitled 'Gender: The Short History of a Critical Term', the feminist theorist and historian Joan Scott who in 1986 introduced the 'layered' model of gender construction mentioned above spoke of the 'millennial fantasy' of a nightmare scenario in which biological determinism would once again rise to reclaim the concept of gender (Scott, 200I). I think it is true today that the once so promising and liberating concept of gender is currently being re-appropriated in various contradictory and sometimes alarming ways. Besides the po- 
tential political setback of 'gender mainstreaming' referred to earlier, in daily usage and common language, gender is increasingly being used as a 'politically correct' term. It is frequently applied in the context of what used to be referred to as 'women's issues'. Additionally, in the English language it is often used, simply as a polite way of referring to biological 'sex' (Scott, 2010). For in popular usage, it routinely comes to stand for the latter term denoting what are understood as the biological (genetic, chromosomal, physical, etc.) differences between women and men. This may be attributed to the influence of a 'new biological determinism' which has come to replace the earlier hold of sociobiological ideas on the roles and status of, and relationships between women, and men as two distinct group of human beings. This biological determinism is often part of the research practices of burgeoning disciplines such as evolutionary and cognitive psychology, micro- and neurobiology, and the field of genetics. I personally am not biophobic, and am not saying that all this research on sexual essential differences is bad or wrong, uninteresting or even irrelevant (in contrast to many of my colleagues in gender studies). Yet, its results do often tend to be selectively translated into simplified and warped messages that filter into the mind of the public at large (think of the marketing hype that promotes the likes of John Gray ("Men are from Mars and women are from Venus") and Allan and Barbara ("Why men don't listen and women can't read maps")'.

The problem with the social constructionist perspective on gender is that in its opposition to biological 'sex', a classical dualistic opposition between nature and culture or between body and mind was reproduced. And then, as Scott remarked in her lecture (200I), "one pole of the divide, sex or biology, became undertheorised in feminist analysis, only to be capitalised by the 'hard' sciences and then in the worst nightmare scenario to come to fully encapsulate 'gender'". Yet, as others have pointed out, the portrayal of gender and feminist theory as generally anti-materialistic is somewhat of a caricature (Ahmed, 2008), and women's and gender studies theorists have been refuting these very dualisms for some time. I will briefly summarize what I identify as the dismantling of the sex-gender distinction - selectively - from four disciplines, namely feminist philosophy, social sciences (in particular socio-cultural anthropology), history and finally biology itself.

\section{Dismantling the Sex-Gender Binary}

The first and probably best-known questioning of the sex/gender divide has been attributed to the influence of postmodern and/or poststructuralist philosophy in feminist theory. In Gender Trouble: Feminism and the Subversion of Identity (I990), US philosopher Judith Butler refuted the sex/gender distinction grounded in a poststructuralist critique of notions of both 'subject' and 'identity', by questioning whether 'the natural facts of sex' may themselves merely be the products of various hegemonic (scientific, juridical, political, etc.) discourses in the service of particular political interests. Butler's primary influence on consecutive feminist theory building has been the argument that if gender

See John Gray's website: http://marsvenus.com and for Allan \& Barbara Pease: http://www.peaseinternational.com/ 
is culturally constructed and does not automatically follow from sex, then 'sex' is proven to be as culturally constructed as 'gender'. A central concept in 'Butlerian' theory is that of 'performance' or 'performativity' (Butler, 1993), by which is meant the discursive practices and acts of repetition through which bodies become engendered in order to present the illusion of fixed identity or, of inner essence or core.

However, the idea as such of the 'doing' or 'making' of gender is by no means entirely novel, and as UK anthropologist Henrietta Moore (I994: 9I) has remarked, not even that 'revolutionary' from the anthropological or social science point of view, which is the second area I will discuss in which the sex/gender distinction has been called into question. Thus, US anthropologists Sylvia Yanagisako and Jane Collier (1987) argue in the late 1980 os that the sex/gender distinction, next to other binary categorisations (nature/ culture, public/private, practical/symbolic, production/reproduction), was simply Eurocentric and part of a Western folk model, thereby questioning its universality and analytic utility. Yanagisako and Collier (1987: 48) claimed: "We question whether the particular biological difference in reproductive function that our culture defines as the basis for difference between males and females, and so treats as the basis of their relationship, is used by other societies to constitute the cultural categories of male and female." Henrietta Moore (1994: 14) has also argued that much ethnographic material suggests that: "Sex, then, as far as we understand it within the terms of western discourse, is something which differentiates between bodies, while gender is a set of variable constructions placed upon those differentiated bodies. It is precisely this formula which obscures rather than illuminates when it comes to the cross-cultural analysis of sex, sexual difference and gender."

In anthropological studies on Africa, the sex/gender distinction has also been challenged by African scholars themselves, such as the work of Nigerian anthropologist, poet and essayist If Amadiume (currently based in the US), who in her book Male Daughters, Female Husbands (I987), challenged the received orthodoxies of social anthropology, by arguing that in pre-colonial society, sex and gender did not necessarily coincide. Examining the structures that enabled women to achieve power, such as in the institution of 'women marriage' in Igbo society, she shows that roles were neither rigidly masculinized nor feminized.

Nigerian sociologist Oyeronke Oyewumi has also been among those to strongly protest against what she sees as the imposition of 'gender' as it is understood in Western feminist discourse, which she similarly claims simply did not exist in Africa prior to the colonial imposition of a dichotomous model of sexual difference that rendered women subordinate, residual and inferior to men. In her book, The Invention of Women, Making sense of African gender discourses (1997), Oyewumi demonstrates, that in traditional Yoruba society, social organization was determined by relative age: "Gender as a universal and timeless social category cannot be divorced from either the dominance of Euro/American cultures in the global system or the ideology of biological determinism which underpins Western systems of knowledge." In a chapter in her recently published volume African Gender Studies, Oyewumi (2005) calls this paradigm that of 'somacentricity'. She acknowl- 
edges that there has been in recent years a so-called 'return to the body', the body which had presumably been 'absent' in those disciplines that set out to explain society on the basis of human interaction rather than biology (so not only in gender studies, but also in sociology, religious studies and so on). However, according to Oyewumi (2005: 5), this return "...discount [s] the fact that the social groups that are the subject matter of this discipline [sociology] [and] are essentially understood as rooted in biology", referring to social categories such as the underclass, farmers, voters, citizens, criminals, etc. In short, Oyewumi (ibid.) claims "There is no escape from biology". Thus, although 'bodylessness' was a precondition of rational thought, "women, primitives, Jews, Africans, the poor, and all those who qualified for the label 'different' in varying historical epochs have been considered to be the embodied, dominated therefore by instinct and affect, reason being beyond them. They are the Other, and other is a body." And, according to Oyewumi, men were seen as nothing but 'walking minds'.

The dichotomous sex/gender dichotomy thus becomes culture-specific rather than universal from the viewpoint of cross-cultural comparison. Thirdly, next to philosophical and anthropological approaches, this dichotomy has also been questioned in historical analysis. Classifications of sex/gender show tremendous variety across space and time. To give but one example, I can refer to the ontology of a one-sex model in pre-modern Europe as hypothesized by the US historian Thomas Laqueur. In his fascinating book Making Sex: Body and Gender from the Greeks to Freud (1990), Laqueur attempts to show how during the pre-Enlightenment period in Western society, the idea of 'sex' as a biological entity did not exist. Until about 1800 , he proposes the 'one sex' model was dominant, according to a worldview in which the primary order was a divine reality. Ontologically, women were simply described and understood as lesser versions of men, as 'but men turned inside out' lacking the 'vital heat', thus causing women to retain body structures that in men were on the outside. Although politically, women were regarded as different and inferior within a societal framework of inequality, sex/gender distinctions as we know them today made no sense.

A fourth area where the sex-gender distinction has been and is being challenged is within biology itself, such as in the work by US professor of biology and gender studies Anne Fausto-Sterling. Fausto-Sterling is known for her proposition, drawn from research on intersexuality and transgenderism, that even at the level of 'sex', the variation is much greater than the two exclusive categories of male and female would show (FaustoSterling, 2000). Scientific criteria for sex determination change over time. As it is today, sex is 'determined' on the basis of the sum of markers at the genetic, cellular, hormonal and/or anatomical level. However, the hold of sexual dimorphic thinking remains strong, as was shown in the Summer of 2009 through the controversy surrounding the South African runner Caster Semenya, who is not the first athlete to have been a 'suspect of gender ambiguity' in the world of sport. However, in this case she did have to endure unseen media attention and hence public and - sometimes racist - humiliation (Dauder \& Gregori, 2009). As a biologist, Fausto-Sterling is a proponent of studying the interplay of biology and culture (recently through the application of dynamic systems theory), by looking at 
biological differences as never being finished, but continually and dynamically reproduced $^{2}$. As such, her work can be aligned with what has recently being identified as 'the new materialism' in feminist theory, a monist approach which claims to move beyond positivist and postmodern epistemologies towards a non-dualist view of the 'embodied subject' (Alaimo \& Hekman, 2008; van der Tuin \& Dolphijn, 2010).

\section{Diversifying Gender Studies}

The third and final topic of this paper addresses the need for gender studies to become more culturally diverse, more global and transnational in their outlook, and the challenges this has brought and continues to bring. In common genealogies of the herstory of women's and gender studies in the US and UK, black feminism and black feminist theory are emphasized for their role in unmasking the false pretence of 'shared sisterhood' together with that of the dominant white, middle class and heterosexual presumptions of feminist analysis, that failed to address the diversity among women and issues of racism and class. Seminal has been the introduction of intersectional thought in gender studies by Afro-American scholars such as legal theorist Kimberlé Crenshaw (1989; 1991) and sociologist Patricia Hill Collins (2000) in the late eighties and early nineties. The latter both argued that modes of oppression within society, such as those based on race/ethnicity, gender, religion, nationality, sexual orientation, class or disability do not act independently of one another. Instead, they interrelate thus creating a system of oppression that reflects the "intersection" of multiple forms of discrimination. Intersectional thought has also been taken up in Europe, for example in the work of Nira Yuval-Davis in the U.K. (forthcoming 20II) and Gloria Wekker and Helma Lutz (200I) in the Netherlands.

Global perspectives, emanating from outside North America and Europe have been fundamental. They have criticized the way Western feminist theory has often and problematically produced the category of the oppressed 'third-world woman'. Chandra Talpade Mohanty (I99I) in her classic, but still highly relevant article 'Under Western Eyes: Feminist Scholarship and Colonial Discourses', shows how in Western feminist texts and scholarship, third-world women are constructed and objectified as 'victims' of particular socio-economic systems, including male violence, Western colonisation, the (Arab) patriarchal familial system, economic development processes, and religious ideologies such as 'the Islamic code'.

Taking these important charges of colonialism and paternalism, and more recently humanism and secularism (implicit in Western feminism) into account, there has been a surge of work within gender studies that attends to the agency of 'other' women within their socio-cultural contexts beyond that of simplistic victimhood (Longman, 2008). There is currently a widespread debate concerning women's religious agency in particular, e.g. the recent work of anthropologist Saba Mahmood (2005) on women's involvement in the Islamic mosque movement in Egypt. Yet, I think caution is required 
to ensure that this trend does not lead to a kind of cultural relativism in which feminism as a political movement and gender studies as a field is dismissed as wholly Western and foreign, and thus irrelevant to non-Western women's and men's lives. Rather, I see such tensions as productive and part and the parcel of what gender studies can be all about.

For example, in a recent reader on African gender scholarship in a series published by the Council for the Development of Social Science Research in Africa, such tensions are obvious from the contributions on what constitutes or could constitute the field of gender studies in Africa. Some of the authors are primarily concerned with 'decolonizing' gender studies in Africa, Kenyan historian Edward Namisiko Waswa Kisiang'ani (2004: Io) for example claims that gender studies in Africa should focus on the "effects of biased Western gender confabulations in Africa and how European prejudices about Africans could be changed." Another contributor to the same book, South African researcher Desiree Lewis (2004), laments the way the field of women and gender studies in Africa continues to bear the imprint of traditional anthropology and developmentalism (by mostly Western scholars on Africa), in which the typical classical ethnographic approach dominated with portrayals of the family, lineage, marriage or kinship is invoked in an effort to demonstrate the radical difference between African and Western societies. African women in this respect are presented as frozen in time and place. Yet, Lewis also points out that the codification of African women's difference did not necessarily and always result in their being denigrated. She indeed finds that this anthropological legacy is also often replicated among indigenous African anthropologists, feeding into fields ranging from feminist theory and politics to gender advocacy. The roles and identities ascribed to African women become the basis for their radical alterity, e.g. identifying 'motherism' as the so-called essence of African womanhood. What I think Lewis might be warning here, reveals some of the difficulties gender studies runs into when preoccupied with cultural differences, or limiting itself to postcolonial critique and deconstructing colonial representation. Lewis (2004: 3I) argues, for example, that in attempts to "codify a pristine Afrocentrism" "[...] the reification of African difference has been marshalled in a variety of ways to build a sense of African unity that mystifies class and gender divides." Or, when some African scholars reject the label 'feminism' in favour of the (more male-friendly) term 'womanism' (introduced by Afro-American scholars in the eighties), Lewis (ibid.) claims, “[...] the argument of congruence between African men and women's struggles can become tricky when a critique of colonialism, neo-colonialism and white feminists' dominance is pitted against an analysis of gender hierarchies in Africa." This position concurs with what Indian, US-based philosopher Uma Narayan (1997) has warned, i.e. that feminist critiques of gender essentialism through paying attention to the differences among women, must be careful not to revert to cultural essentialism. For third world feminists, indigenous feminists or minority women activists, wherever they may be in the world and under whatever name, they may manifest themselves as 'cultural betrayers', as 'rooted in elitist and "Westernized" views of their cultures'. By contrast, Narayan 
(1997: 397) argues that “...for many Third World feminists, their feminist consciousness is not a hot-house bloom grown in the arid atmosphere of 'foreign' ideas, but has its roots much closer to home".

\section{Concluding Notes}

The many tensions within gender studies that have been extensively debated for more than three decades now and continue to be discussed, (including those I have touched upon above: women or gender, nature or culture and cross-cultural diversity) attest to a huge and still growing amount of scholarship and thought. This amounts to a body of work of such scope as to constitute, I think, a discipline in its own right, a range that is impossible to contain in just one elective course, or a yearly lecture series or a special symposium topic. Mainstreaming gender perspectives within classical disciplines or courses only occurs sporadically, and is usually dependent on individual lecturers' research interests rather than the result of any systematic attempts at organisation. Unfortunately, in practice, and as is probably the case worldwide, gender studies in academia is more often than not treated with suspicion, regarded as marginal and is continuously under threat. Yet, this is also symptomatic of many fields where critical thought is being generated and taught, real-life inequalities are addressed and myths of sameness and difference are being dispelled. For these reasons alone, I think, if given the chance, gender studies, in its various forms and locations, still have an important contribution to make.

\section{References}

Ahmed, S. (2008). Open Forum Imaginary Prohibitions: Some Preliminary Remarks on the Founding Gestures of the 'New Materialism'. European Journal of Women's Studies, I5, (I): 23-39.

Alaimo, S. \& Hekman, S. (Eds.) (2008). Material Feminisms. Bloomington \& Indianapolis: Indiana University Press.

Amadiume, I. (1987). Male Daughters and Female Husbands: Sex and Gender in an African Society. London \& New Jersey: Zed Books.

Arnfred, S. (2004). Gender Research in Africa: Dilemmas and Challenges as seen by an Outsider. In S. Arnfred, B. Bakare-Yusuf, E. Waswa Kisiang'ani et al. (Eds.), African Gender Scholarship: Concepts, Methodologies and Paradigms (pp. 82-100). Dakar \& Oxford: Council for the Development of Social Science Research in Africa.

Butler, J. (1990). Gender Trouble: Feminism and the Subversion of Identity. New York and London: Routledge.

- (1993). Bodies That Matter: On the Discursive Limits of 'Sex'. New York and London: Routledge.

Crenshaw, K. (1989). Demarginalizing the Intersection of Race and Sex: A Black Feminist Critique of Antidiscrimination Doctrine, Feminist Theory and Antiracist Politics. University of Chicago Legal Forum, 139-167.

- (1991). Mapping the Margins: Intersectionality, Identity Politics, and Violence against Women of Color. Stanford Law Review 43, 124I-1279.

Dauder, S. G. \& Gregori, N. (2009). Designing the Margin of Feasible Bodies: Truths and Binary Oppositions in the Construction of Sexes-Genders-Sexualities. Eurozine, 28 September 2009 [http://www.eurozine.com/ articles/2009-09-28-garciadauder-en.html] (First published in L'Espill 31, 2009).

De Beauvoir, S. (2010). The Second Sex. (transl. by C. Borde \& S. Malovany-Chevallier), Random House (orig. Gallimard 1949).

De Volkskrant, Vrouwenstudies in de knel, 23/09/2003 [http://www.volkskrant.nl/archief_gratis/article979266.ece/Vrouwenstudies_in_de_knel]. 
Fausto-Sterling, A. (2000). Sexing the Body: Gender Politics and the Construction of Sexuality. New York: Basic Books.

Griffin, G. \& Braidotti, R. (2002). Introduction: Configuring European Women's Studies. In: G. Griffin \& R. Braidotti (Eds.). Thinking Differently: A Reader in European Women's Studies (pp. I-28). London \& New York: Zed Books.

Haraway, D. (1988). Situated Knowledges: The Science Question in Feminism and the Privilege of the Partial Perspective. Feminist Studies, I4, 3, 575-99.

Hawkesworth, M. (1997). Confounding Gender. Signs: Journal of Women in Culture and Society, 22, (31), 649-686.

Hill Collins, P. (2000). Black Feminist Thought: Knowledge, Consciousness, and the Politics of Empowerment. Second Edition. New York \& London: Routledge (orig. 1990).

Kisiang'ani, E. N.W. (2004). Decolonising Gender Studies in Africa. In: S. Arnfred et al. African Gender Scholarship: Concepts, Methodologies and Paradigms (pp. 9-26). Dakar \& Oxford: Council for the Development of Social Science Research in Africa.

Laqueur, T. (1990). Making Sex: Body and Gender from the Greeks to Freud, Cambridge, Massachusetts: Harvard University Press.

Letter to the bishops of the Catholic Church on the collaboration of men and women in the church and in the world (2004). [http://www.vatican.va/roman_curia/congregations/cfaith/documents/rc_con_ cfaith_doc_2004073I_collaboration_en.html].

Lewis, D. (2004). African Gender Research and Postcoloniality: Legacies and Challenges. In: S. Arnfred et al. African Gender Scholarship: Concepts, Methodologies and Paradigms, pp. 27-4r. Dakar \& Oxford: Council for the Development of Social Science Research in Africa.

Longman, C. (2008). Sacrificing the Career or the Family? Orthodox Jewish Women in between Secular Work and the Sacred Home. European Journal of Women's Studies, special issue 'Questioning the Secular', 15, (3), 223-239.

Mahmood, S. (2005). Politics of Piety: The Islamic Revival and the Feminist Subject. Princeton: Princeton University Press.

Mead, M. (200I). Coming of Age in Samoa: A Psychological Study of Primitive Youth for Western Civilisation. Harper Perennial Modern Classics (orig. 1928).

- (2002). Sex and Temperament: In Three Primitive Societies. Harper Perennial Modern Classics (orig. 1935).

Mohanty, C.T. (1991). Under Western Eyes: Feminist Scholarship and Colonial Discourses. In: C.T. Mohanty, A. Russo \& L. Torres (Eds.). Third World Women and The Politics of Feminism, (pp. 51-80). Bloomington and Indianapolis: Indiana University Press.

Moore, H. (1994). A Passion for Difference: Essays in Anthropology and Gender. Cambridge: Polity Press.

Narayan, U. (1997). Dislocating Cultures: Identities, Traditions and Third World Feminism. New York \& London: Routledge.

Oakley, A. (1996). Sex, Gender and Society. Aldershot: Arena (orig. 1972).

Outshoorn, J. (1998). Gender: revolutie en risico. Tijdschrift voor Genderstudies, I, (I): 5-6.

Oyeronke O. (1997). The Invention of Women: Making an African Sense of Western Gender Discourse. Minneapolis: University of Minnesota Press.

- (2005). Visualizing the Body: Western Theories and African Subjects. In: O. Oyeronke (Ed.). African Gender Studies: A Reader (pp. 3-21). New York \& Basingstoke: Palgrave Macmillan.

Scott, J.W. (1996). Gender: A Useful Category of Historical Analysis. In: J.W. Scott (Ed.). Feminism and History (pp. 152-180). Oxford and New York: Oxford University Press (orig. in: American History Review, 1986, 91/5, 1053-1075). 
- (200I). Millennial Fantasies: The Future of Gender in the 21st Century. Die Zukunft von Gender: Fantasien zur Jahrtausendwende. In: C. Honegger \& C. Arni (Eds.), Gender. Die Tuecken einer Kategorie. Joan W. Scott, Geschichte und Politik - Beitraege zum Symposion anlässlich der Verleihung des Hans-SigristPreises 1999 der Universitaet Bern an Joan W. Scott (pp. 19-37). Zurich, Switzerland: Chronos.

(2010). Gender: Still a Useful Category of Analysis? Diogenes, 225, 7-14.

Shankman, P. (2009). The Trashing of Margaret Mead: Anatomy of an Anthropological Controversy. University of Wisconsin Press.

Van der Tuin, I. \& Dolphijn, R. (2010). The Transversality of New Materialism. Women: A Cultural Review, 2I, 2, I53-I7I.

Wekker, G. \& Lutz, H. (200I). Een hoogulakte met koude winden. De geschiedenis van het gender- en etniciteitsdenken in Nederland. In: M. Botman, M.N. Jouwe \& G. Wekker (Eds.). Caleidoscopische visies. De zwarte, migranten en vluchtelingenvrouwenbeweging in Nederland (pp. 25-49). Amsterdam: Koninklijk Instituut voor de Tropen.

Yanagisako, S.J. \& Collier, J.F. (1987). Toward a Unified Analysis of Gender and Kinship. In: Collier, J. F. \& Yanagisako, S. J. (Eds.). Gender and Kinship: Essays Toward a Unified Analysis (pp.14-5I). Stanford: Stanford University Press.

Yuval-Davis, N. (forthcoming 2011). Intersectional Politics of Belonging. London: Sage. 